\title{
Evidence of high Ba-Sr granites in the Adamello Batholith, Southern Alps
}

\author{
ANGELICA MOSCONI, MASSIMO TIEPOLO, FEDERICO \\ FARINA AND ENRICO CANNAO \\ Università degli Studi di Milano \\ Presenting Author: angelica.mosconi@unimi.it
}

Modern analogues of Archean granitoids are unique rocks that allow investigating processes of continental crust formation and their variations through Earth's evolution.

New field data on the Corno Alto unit of the Adamello batholith revealed the occurrence of three types of granitoid rocks: i) a two-mica granodiorite; ii) a subordinate hornblendebearing tonalite; iii) a hornblende- and biotite-bearing granodiorite. Plagioclase is the dominant phase in all these rocks and is ubiquitously characterized by oscillatory zoning and by the occurrence of partially resorbed and ghost cores testifying conditions of intense chemical disequilibrium.

The whole rock composition of the studied rocks reveals peculiar features compared to the rest of the Adamello batholith. In particular, the Corno Alto granitoids are characterized by the highest $\mathrm{SiO}_{2}\left(61 \leq \mathrm{SiO}_{2} \leq 71.5 \mathrm{wt} \%\right)$ and $\mathrm{K}_{2} \mathrm{O}+\mathrm{Na}_{2} \mathrm{O}$ (up to $7.2 \%$ ) contents as well as by a strong enrichment in $\mathrm{Sr}$ and $\mathrm{Ba}$ $(\mathrm{Sr}+\mathrm{Ba} \approx 1100-1900)$. Other significant features are the relatively high LREE/HREE ratios $\left([\mathrm{La} / \mathrm{Yb}]_{\mathrm{N}}>20\right)$ and $\mathrm{Nb}$ negative anomaly. Major, trace and isotopic compositional traverses across plagioclase grains reveal abrupt chemical variations coupled with different $\mathrm{Sr}$ radiogenic signatures..

The whole rock composition of the Corno Alto granitoid rocks resemble that of a peculiar group of Phanerozoic rocks. These are the high $\mathrm{Ba}-\mathrm{Sr}$ granites which are considered as modern analogues of the Archean sanukitoids originated from the interaction between mantle peridotite and a component from the subducted sediments [2]. Microscale elemental and isotopic variations, as well as the occurrence of multiple U-Pb age clusters, contrast with an origin of the studied rocks either in closed system or from a simple AFC process. Mixing of melts with different geochemical signatures and recycling of older crystals is required.

Deciphering the origin of the different components contributing to the petrogenesis of the alpine high $\mathrm{Sr}-\mathrm{Ba}$ granitoids may help settling critical issues concerning the formation of sanukitoids in the late Archean, in particular concerning their mantle origin and how they differentiate at shallow crustal levels.

[2] Martin et al., (2005) Lithos 79, 1-24. 